\title{
Treehopper (Membracidae, Auchenorrhyncha) assemblages in four semi-arid areas of caatinga of Northeast Brazil
}

\author{
Rembrandt Romano Andrade Dantas Rotheá ${ }^{1,2}$, Aline Lourenço ${ }^{1,2}$, Alexandre Vasconcellos ${ }^{1,2} *$ (ib $\&$ \\ Antonio José Creão-Duarte ${ }^{1,2}$ \\ ${ }^{1}$ Universidade Federal da Paraíba, Centro de Ciências Exatas da Natureza, Departamento de Sistemática e \\ Ecologia, CEP 58051-970, João Pessoa, PB, Brasil \\ ${ }^{2}$ Universidade Federal da Paraíba, Programa de Pós-Graduação em Ciências Biológicas, \\ CEP 58051-970, João Pessoa, PB, Brasil \\ *Corresponding author: Alexandre Vasconcellos, e-mail: alextermites@gmail.com
}

ROTHEÁ, R.R.A.D., LOURENÇO, A., VASCONCELlOS, A., CREÃO-DUARTE, A.J. Treehopper (Membracidae, Auchenorrhyncha) assemblages in four semi-arid areas of caatinga of Northeast Brazil. Biota Neotropica. 19(2): e20180602. http://dx.doi.org/10.1590/1676-0611-BN-2018-0602

\begin{abstract}
Treehopper assemblages were sampled in four semi-arid areas of caatinga in Northeast Brazil during the rainy seasons of 2016 and 2017, using three different capture methods. The areas are located in two Ecoregions of the Caatinga: "Depressão Sertaneja Setentrional" (Northern Sertaneja Depression) and "Planalto da Borborema" (Borborema Plateau). A total of 2,394 individuals of 43 species were sampled, corresponding to approximately $87 \%$ of the mean estimated species richness for all four areas. The species richness varied among the areas from 14 to 21, while the abundance of individuals ranged from 129 to 1860. Eighteen species were shared among areas, of which only Enchenopa eunicea, Sundarion sp. 1, Ceresa vitulus and Erosne parvula occurred in all four due to the general behavior of the first three and the wide distribution of host plant of Erosne parvula - Mimosa tenuiflora. Twenty-five species occurred only in one area, of which 23 were categorized as rare with a maximum of eight individuals sampled, and seven with only one individual collected (singletons). Considering that the Caatinga Domain possesses at least nine Ecoregions with different climates, geomorphology and vegetation, along with marked endemism of plants, it is expected that the species richness of treehoppers will increase substantially on a regional scale.

Keywords: biodiversity, Neotropical Region, host plants, treehoppers.
\end{abstract}

\section{Taxocenoses de membracídeos (Membracidae, Auchenorrhyncha) de quatro áreas de caatinga do semi-árido do nordeste do Brasil}

Resumo: As taxocenoses de membracídeos foram amostradas em quatro áreas de Caatinga do semiárido do Nordeste brasileiro, durante a estação chuvosa de 2016 e 2017, utilizando três métodos distintos de captura. Essas áreas estão inseridas em duas Ecorregiões da Caatinga, Depressão Sertaneja Setentrional e Planalto da Borborema. Um total de 2.394 indivíduos pertencentes a 43 espécies foram amostrados, correspondendo a aproximadamente $87 \%$ da riqueza de espécies média estimada para o conjunto das quatro áreas. A riqueza de espécies por área variou de 14 a 21, enquanto a abundância de indivíduos variou de 129 a 1860. Dezoito espécies foram compartilhadas, mas apenas Enchenopa eunicea, Sundarion sp. 1, Ceresa vitulus e Erosne parvula ocorreram em todas as áreas, em decorrência do comportamento generalista das três primeiras espécies e da distribuição ampla da planta hospedeira de Erosne parvula - Mimosa tenuiflora. Vinte cinco espécies foram exclusivas, ocorrendo em apenas uma das áreas, sendo 23 dessas categorizadas como raras, com no máximo oito indivíduos amostrados, e sete com apenas um único indivíduo coletado (singletons). Tendo em vista que o Domínio da Caatinga possui, pelo menos, nove Ecorregiões, com diferentes características de clima, geomorfologia e vegetação, inclusive com uma marcante taxa de endemismo de plantas, há expectativa que a riqueza de espécies de membracídeos possa aumentar substancialmente numa escala regional.

Palavras-chave: biodiversidade, Região Neotropical, plantas hospedeiras, membracideos. 


\section{Introduction}

Treehoppers (Membracidae) are phytophagous hemiptera of the suborder Auchenorrhyncha. They frequently go unnoticed by most people because the elaborated form of the pronotum often resembles parts of the plant son which they occur Deitz 1975. They are mostly found on the most sun-exposed parts of their host plants (Funkhouser 1951), such as new branches, inflorescences and infructescences (Haviland 1925), where they suck sap and, as result, excrete honeydew, which attracts mainly bees and ants with which they establish mutualistic relationships (Loye 1987, Del Claro \& Oliveira 1999, Delabie 2001).

The treehopper fauna, and their geographic distributions, were initially recorded systematically by Funkhouser (1927). Supplements to this first catalog have since been published (Metcalf \& Wade 1965, McKamey 1998). The last supplement included about 3,300 species distributed in six zoogeographic regions, the richest being the Neotropical Region with about $43 \%$ of the total species. Currently, 686 species have been recorded in Brazil (Evangelista et al. 2018), but the real richness is likely much higher considering the low number of researchers in the country devoted to the group, numbers gaps in sampling of the main phytogeographic domains of Brazil and difficulties accessing canopy fauna, where most of the species occur.

The Caatinga encompasses an area of $912,529 \mathrm{~km}^{2}$, representing $10.7 \%$ of the area of Brazil, and is composed of Seasonally Dry Tropical Forests (SDTFs) of the Neotropical Region (Silva et al. 2017). A significant proportion of the country's population lives in this region, but since no public policy for maintaining ecosystems was in effect during their occupation, less than $2 \%$ of the area is protected as full protection Conservation Areas (Tabarelli et al. 2000). The rhetoric that prevailed in the past, that the Caatinga harbored few species and therefore had low conservation priority, no longer finds support among the scientific community. The high number of endemic species described each year is a testament to their differentiated diversity and, at the same time, to the lack of knowledge about them (Bellini 2014, Mariano \& Costa 2014, Carvalho \& Bravo 2014, Lecci et al. 2014, Vasconcellos \& Moura 2014, Creão-Duarte et al. 2017, Ernesto et al. 2018).

The climate of the Caatinga is marked by two well-defined seasons (drought and rain) that affect the dynamics of all the biotic components of the ecosystem. Precipitation and relative humidity are the main climatic variables that predict an increase in plant biomass, which in turn substantially alter the life cycle of animals and, consequently, all the biological activities performed by these organisms (Vasconcellos et al. 2010). The rainy season determines significant changes in the abundance of insects (Gusmão \& Creão Duarte 2004, Iannuzzi et al. 2006, Vasconcellos et al. 2010, Liberal et al. 2011) and, consequently, increases in reproduction, predation, parasitism (Fogden 1972, Wolda 1978) and foraging (Janzen \& Schoener 1968).

Research on treehoppers (Membracidae) of the Caatinga has had the aim of describing new species (Creão-Duarte \& Rothéa 2006, Rothéa \& Creão Duarte 2007) or emphasizing aspects of their ecology, such as insect/host plant relationships (Creão-Duarte et al. 2012, 2016). Strictly speaking, the present study represents the first systematized effort to inventory the fauna of Membracidae in the Caatinga by describing its abundance and species richness in four areas of located in two Ecoregions of Northeast Brazil.

\section{Material and Methods}

\section{Study areas}

The study was developed in four areas of caatinga in the state Paraíba, Brazil. (i) RPPN Fazenda Almas (RPFA) (centered approximately at $7^{\circ} 28^{\prime} 12^{\prime} \mathrm{S}, 36^{\circ} 53^{\prime} 52^{\prime} \mathrm{W}$ ): this area is located in the municipalities of São José dos Cordeiros and Sumé, has an area of 3,505 ha and a maximum elevation of $720 \mathrm{~m}$. The mean annual precipitation is $600 \mathrm{~mm}$, and the climate is classified as BSh (Köppen 1948). The vegetation is open arboreal, with low levels of anthropic disturbance (Lima \& Barbosa 2014, Barbosa et al. 2015). (ii) Serra de Santa Catarina (SESC) (centered at approximately $7^{\circ} 00^{\prime} 46^{\prime \prime} \mathrm{S}, 38^{\circ} 11^{\prime} 12^{\prime \prime} \mathrm{W}$ ): this area is located in the municipalities of Nazarezinho and São José da Lagoa Tapada, has an area of 11,210 ha, and a maximum elevation of $830 \mathrm{~m}$. The mean annual precipitation is $892 \mathrm{~mm}$, and the climate is classified as 4ath, that is, hot tropical and markedly dry (Bagnolds. \& Gaussen 1963). Seasonal deciduous caatinga occurs in areas at higher elevations, and possess high aerial biomass and great potential for conservation of Caatinga biodiversity (Giulietti et al. 2003, Ernesto et al. 2018). (iii) Parque Ecológico Engenheiro Ávidos (PEEA) (659’12”S, $\left.38^{\circ} 27^{\prime} 22^{\prime \prime} \mathrm{W}\right)$ : this area is located in the municipality of Cajazeiras, has area of 181.98 ha and a maximum elevation of $290 \mathrm{~m}$. The mean annual precipitation is $870 \mathrm{~mm}$, and the climate is classified as $A w$ (Köppen). The vegetation is shrubby and open, and exhibits clear signs of recent anthropic impacts (Feitosa et al. 2002). (iv) Parque Estadual da Pedra da Boca (PEPB) $\left(6^{\circ} 27^{\prime} 32^{\prime \prime} \mathrm{S}, 35^{\circ} 40^{\prime} 38^{\prime \prime} \mathrm{W}\right)$ : this area is located in the municipality of Araruna, has an area of 157 ha and a maximum elevation of $400 \mathrm{~m}$. The mean annual precipitation is $950 \mathrm{~mm}$, and the climate is classified as BSh (Köppen). The vegetation is shrubby with high levels of anthropic disturbance. The first three study areas are located in the "Depressão Sertaneja Setentrional" (Northern Sertaneja Depression) and the last in "Planalto da Borborema" (Barborema Plateau), according to the classification of Caatinga Ecoregions proposed by Velloso et al. (2002).

\section{Collection protocol}

Treehoppers were captured in each area during four expeditions during the rainy season of 2015 (PEEA and PEPB) and 2016 (RPFA and SESC), using three methods: yellow adhesive cards, light traps and active collection. The two-sided $(11 \times 21 \mathrm{~cm})$ adhesive cards (PROMIP ${ }^{\circledR}$ ) were arranged in the study areas at two heights - up to $1.5 \mathrm{~m}$ and the tree canopy - separated from each other by at least $20 \mathrm{~m}$ and from the edge by $50 \mathrm{~m}$. The cards were thrown into the canopy with the help of a slingshot, $\left(\right.$ Durepox $\left.^{\circledR}\right)$ spheres and throwing lines. Thirty cards were placed at each height for a total of 60 cards per area. Each card was considered a sample unit and remained in the field for five days. The insects collected with adhesive cards were removed from the glue using Varsol $^{\circledR}$ solvent for $24 \mathrm{~h}$ followed by acetone.

The light trap was equipped with a $250 \mathrm{w}$ and $220 \mathrm{v}$ mixed mercury light, powered by a $60 \mathrm{~Hz}$ and $\sim 700 \mathrm{~W}$ portable gasoline generator, against a white fabric background $(2.0 \times 2.0 \mathrm{~m})$. For this method, 90 minutes of collection was considered a sample unit, with 10 sample units being performed in each area. The distance between traps was $100 \mathrm{~m}$. 
Active collection was performed along a transect of about $1,200 \mathrm{~m}$, distributed along trails and in the edges of the forest, using an entomological net, plastic bags and killing-jars to capture insects seen up to the reach height of the entomological net (about $4 \mathrm{~m}$ ). Active collection sampled a total of 30 sampling units of $30 \mathrm{~m}$ each spaced at $10 \mathrm{~m}$ intervals along the transect.

The entire collection protocol employed four people experienced in collecting treehoppers over the course of five days at a cost $\$ 200$ per area, including food, adhesive cards and fuel. After mounting and drying, the specimens were incorporated into the Coleção (Entomológica) do Departamento de Sistemática e Ecologia (DSEC)/UFPB.

\section{Data analysis}

EstimateS 9.1 software (Colwell 2000) was used to estimate species richness through the Chaol estimator and to construct the collector curve. In this case, as the abundances are very different between the areas, we chose to relate the richness to the number of samples, which had the same strength per area, one hundred samples. In all cases the data were submitted to 1000 randomizations without replacement (Walther \& Moore 2005, Colwell 2006). The amount of additional effort, in terms of individuals required to reach $95 \%(\mathrm{~g}=0.95)$ and $100 \%(\mathrm{~g}=1)$ of the estimated richness was calculated by Chao et al. (2009). Finally, differences in species composition between areas were illustrated using a Venn diagram constructed with Venny 2.1 software (Oliveros 2015).

\section{Results}

A total of 2,394 treehoppers, belonging to 43 species and 24 genera, were collected in the four caatinga areas (Table 1). The total species richness sampled (43 spp.) corresponded to $93,26 \%$ of total estimated richness (46.11 spp.) (Table 2) and the additional effort to reach $95 \%$ $(\mathrm{g}=0.95)$ and $100 \%(\mathrm{~g}=1)$ of the species richness in the areas would require an increase in the collection effort to 1,300 and 4,391 individuals, respectively.

The observed species richness varied among areas, ranging from 14 to 21 , with estimates ranging from $14.0 \pm 0.1$ to $26.0 \pm 5.5$ (Chao1) (Table 1 and 2). The trend-lines produced (the species accumulation curves) suggest that increased sampling effort in SESC and PEPB would have a high likelihood increasing significantly the species richness of these areas (Figure 1).

The number of individuals per area ranged from 129 (RPFA) to 1,860 (SESC), with Melusinella nervosa being the most abundant in two of the areas. More broadly, dominance of the assemblages was such that only three species, Melusinella nervosa, Erosne parvula and Sundarion sp. 1, were responsible for approximately $79 \%$ of all the individuals (Table 1). In the set of assemblages, seven species had only one individual collected (singletons), with areas possessing 1 (PEEA), 2 (PEPB) and 4 (SESC).

Eighteen species were shared between two, three or four areas, with Erosne parvula, Sundarion sp. 1, Enchenopa eunicea and Ceresa vitulus being the species that were collected in all areas or, in other words, $9.3 \%$ of the species. However, the number of exclusive species was 25, with SESC being the area with the highest number of species (12) in this category (Figure 2).

\section{Discussion}

When the species richness of the present study (43 spp.) is combined with other pre-existing records in DSEC Entomological Collection, the total treehopper species richness for the Caatinga in Paraíba reaches 64. Furthermore, $30(46,8 \%)$ of these species represent exclusive records for the Caatinga Domain of this state and so have a high likelihood of being endemic species. In addition, 20 species of this total may be new to science, although only two Ecoregions of the Caatinga have been explored: "Depressão Sertaneja Setentrional" (RPFA, SESC and PEEA) and "Planalto da Borborema" (PEPB).

Treehoppers are phytophagous insects and the dominance of these species in an environment is a function of an equally abundant occurrence of plants (resources) that hosts these Hemiptera (Wallace, 2008). Melusinella nervosa was the most abundant species in the present study, having been recorded in three of the four areas and with 1,509 individuals having been captured in RPFA alone, where its most important host plant, Sida galheirensis Ulbr. (Malvaceae), occurs in abundance as well. In a study of niche overlap in the Caatinga, using only active collection, Enchenopa concolor, E. eunicea and E. minuta were found to be the most abundant species, and were collected in association with eight, nine and four species of host plants, respectively (Creão-Duarte et al. 2012).

The number of species shared by two or more areas (18) was less than the number of exclusive species (25). We believe that the sharing of species between areas may be more likely for generalist species or when a species-specific host is widely distributed. Enchenopa eunicea, Erosne parvula, Sundarion sp. 1, and Ceresa vitulus, were the only species shared by all four areas of the present study. Of these, $E$. eunicea is a generalist species, Sundarion $s p$. and Ceresa vitulus have been recorded for four host plants, and Erosne parvula was collected on Mimosa tenuiflora (Wild.) Poiret (Fabaceae), a common Caatinga plant, with eight species of treehoppers already recorded using it as a host in this domain (Creão-Duarte et al. 2012).

Among the exclusive species (25), 23 were represented by eight or fewer individuals; that is, they were rare species in the assemblage (Table 1), but host specificity among treehoppers is more relevant to species of temperate regions, since tropical species tend to be polyphagous (Wood 1984, 1993). Lopes (1995) listed 26 species of treehoppers for the Cerrado, which occurred on 40 species of host plants, about $27 \%$ of which were recorded for a single host plant. The scope of this study, however, did not seek to identify host plants, although a study of Membracidae niche overlap in the Caatinga found that only about $15 \%$ of the species were associated with a single host; thus, the generalization of Wood $(1984,1993)$ also applies to Caatinga treehoppers.

Comparing the 26 species collected in a locality of the Cerrado by Lopes (1995) with the 43 species collected in the Caatinga reveals that only three species are common to both biomes: Enchenopa concolor, Enchenopa gracilis and Prorcyrta pectoralis. The two species of Enchenopa have broad distributions, ranging from Central America to southern Brazil (McKamey 1998). In the Cerrado, E. concolor was only recorded on Bauhinia holophylla Steud (Leguminosae), while $E$. gracilis was recorded on six host plants from six different botanical families. In the Caatinga, E. concolor was recorded on eight different 
Rotheá, R.R.A.D. et al.

Table 1. Species richness and abundance of Membracidae in four areas of caatinga in the state of Paraíba, Brazil.

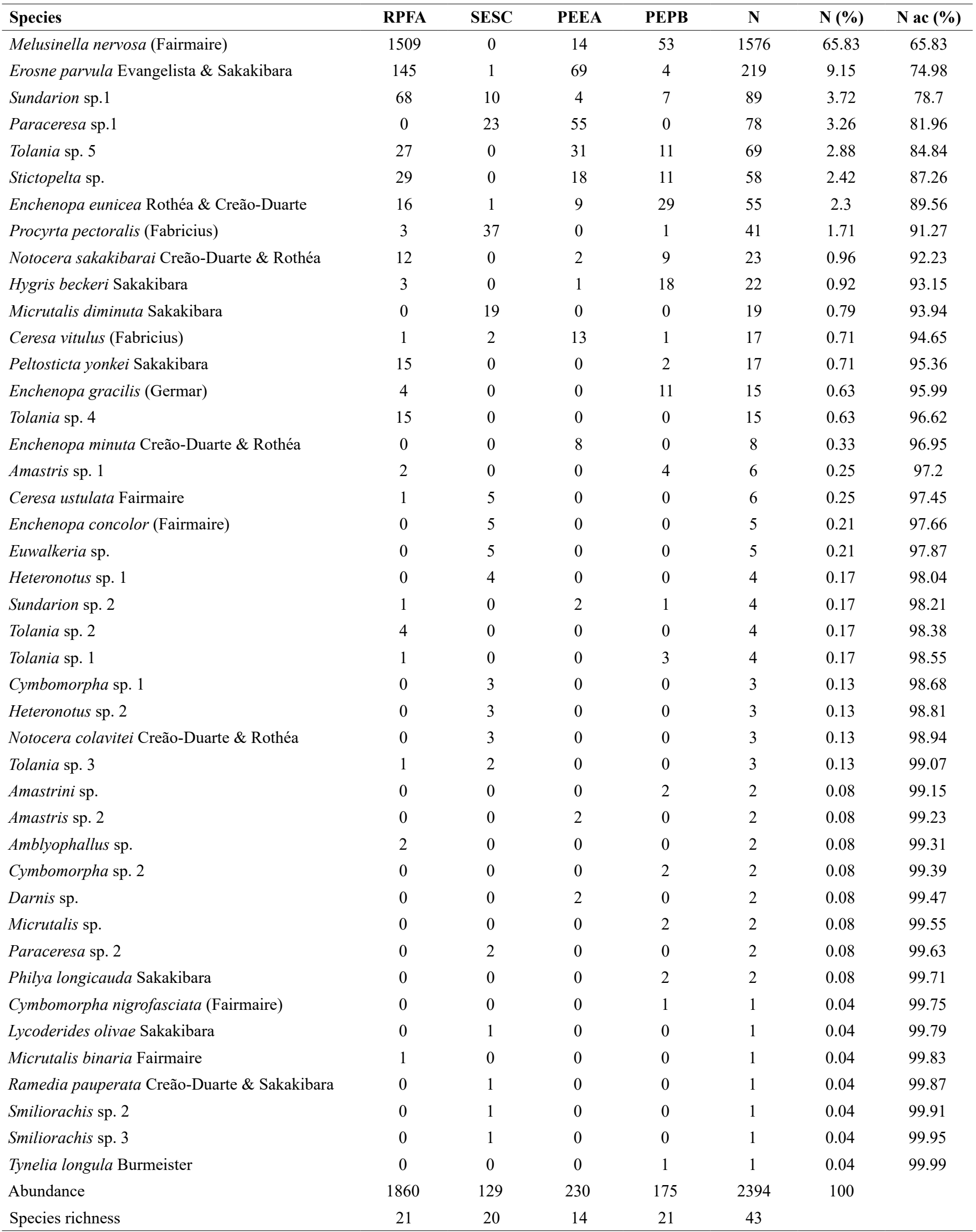


Table 2. Values of richness observed and estimated.

\begin{tabular}{lccccc}
\hline & RPFA & SESC & PEEA & PEPB & TOTAL \\
\hline Species Richness & 21 & 20 & 14 & 1 & 5 \\
Singletons & 6 & 6 & 4 & 5 & 7 \\
Doubletons & 2 & 3 & $14.0 \pm 0.1$ & $22.7 \pm 2.2$ & 8 \\
Chao 1 1 SD & $26.0 \pm 5.5$ & $23.7 \pm 4.2$ & 100.00 & 90.09 & $46.11 \pm 3.1$ \\
Sampled richness \% & 80.77 & 84.39 & 93.26 \\
\hline
\end{tabular}

The column "TOTAL" represents the combining of the four areas into 400 sample units.

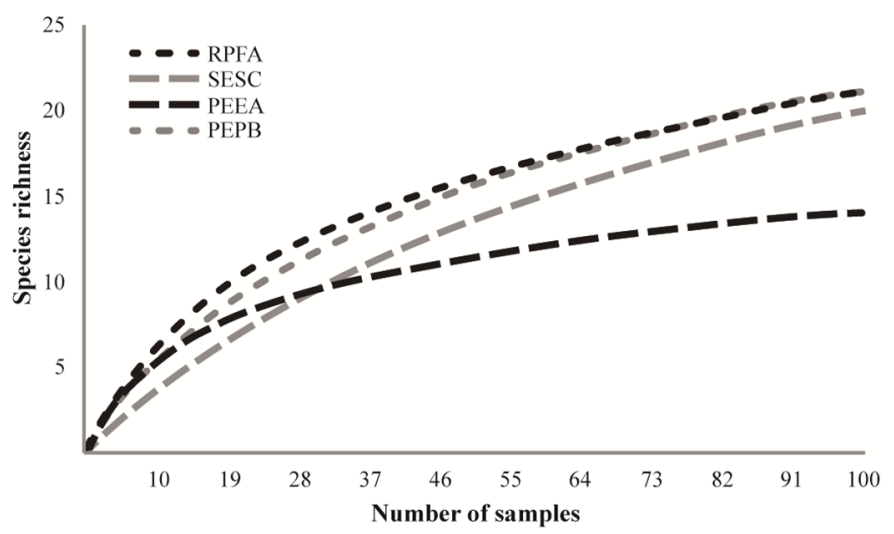

Figure 1. Species accumulation curves for four areas of caatinga in the state of Paraíba, Brazil.

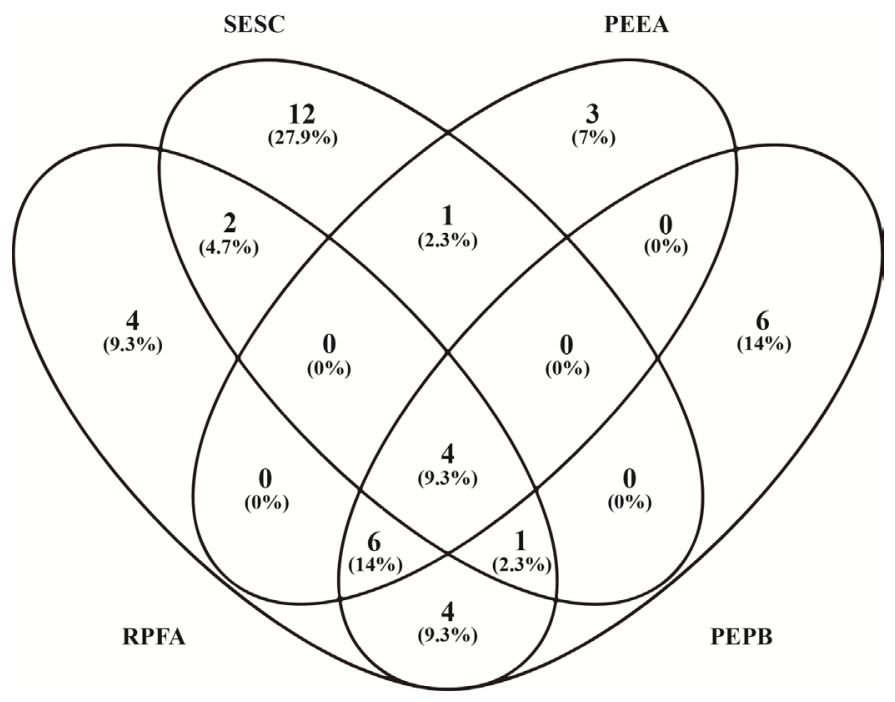

Figure 2. Venn diagram for species of Membracidae, exclusive and shared, in four areas of caatinga in the state of Paraíba, Brazil.

plant species, the most common being Indigofera suffruticosa Mill. (Fabaceae) (Creão Duarte et al. 2012). The low proportion of common species found between the domains may be historical and indicate that the Caatinga and Cerrado are not the result of a single ancestral area, as stated by Zanella (2010).

The species accumulation curves for each area translate the richness estimates obtained with the Chaol estimator. The PEEA curve was the only one that approached the asymptote, but the stopping rule was not met due to the occurrence of a singleton, Hygris beckeri. In the other three areas it was not possible to identify any stability trend and the curves indicate that additional sampling efforts should be directed to them in order to reach $95 \%$ and $100 \%$ of the estimated richness.

The Caatinga Domain makes up the richest area of Dry Seasonal Tropical Forest in the New World, where more than 3,000 plant species are found with an estimated endemism of 23\% (Queiroz et al. 2017). In this domain, which corresponds to $10.7 \%$ of the national territory, there are at least 13 compositions of different vegetal physiognomies distributed among nine distinct ecoregions (Veloso et al. 2002, Silva et al. 2017). The heterogeneity of the Caatinga, the low similarity between the sampled assemblages of treehoppers in different areas and the large sampling gaps in this domain suggest that the biodiversity of these insects will increase substantially with increased sampling effort, especially in ecoregions not yet explored.

\section{Acknowledgments}

The authors would like to thank Josimar Bezerra (SESC) for the fieldwork assistance and José Roberto (RPFA). RRADR and AL thanks CAPES (Coordenação de Aperfeiçoamento de Pessoal de Nivel Superior) for the scholarship. AV thanks CNPq (Conselho Nacional de Desenvolvimento Científico e Tecnológico) for the research grant (proc. 304210/2017-0).

\section{Authors Contributions}

Rembrandt Romano Andrade Dantas Rothéa: Substantial contribution in the concept and design of the study; Contribution to data collection; Contribution to data analysis and interpretation; Contribution to manuscript preparation and critical revision, adding intellectual content.

Aline Lourenço: Substantial contribution in the concept and design of the study; Contribution to data collection; Contribution to data analysis and interpretation; Contribution to manuscript preparation and critical revision, adding intellectual content.

Alexandre Vasconcellos: Substantial contribution in the concept and design of the study; Contribution to data analysis and interpretation; Contribution to manuscript preparation and critical revision, adding intellectual content.

Antonio José Creão-Duarte: Substantial contribution in the concept and design of the study; Contribution to data collection; Contribution to data analysis and interpretation; Contribution to manuscript preparation and critical revision, adding intellectual content. 


\section{Conflicts of interest}

The authors declare that they have no conflict of interest related to the publication of this manuscript.

\section{References}

BAGNOLDS, F. \& GAUSSEN, H. 1963. Os Climas Biológicos e sua Classificação. Boletim Geográfico, Rio de Janeiro, 22(176): 545-566.

BELLINI, B.C. 2014. Fauna de Collembola (Arthropoda) em áreas úmidas do semiárido. In Artrópodes do Semiárido. Biodiversidade e Conservação (F. Bravo \& A. Calor, eds.). Printmídia, Feira de Santana, p.57-68.

CARVALHO, J. DE \& BRAVO, F. 2014. Odonata do semiárido. In Artrópodes do Semiárido. Biodiversidade e Conservação (F. Bravo \& A. Calor, eds.). Printmídia, Feira de Santana, p.83-90.

CHAO, A., COLWELL, R.K, CHIH-WEI L., \& GOTELLI, N.J. 2009. Sufficient sampling for asymptotic minimum species richness estimators. Ecology. 90(4): 1125-1133.

COLWELL, R.K. 2000. Statistical estimation of species richness and shared species from samples. Version 9 and earlier. User's Guide and application. University of Connecticut.

COLWELL, R.K. 2006. User's guide to Estimates statistical. Estimation of species richness and shared species from samples. http://viceroy.eeb.uconn. edu/estimates (last access in 15/jun/2017).

CREÃO-DUARTE, A.J. \& ROTHÉA, R.R.A.D. 2006. A new species of Calloconophora Dietrich (Hemiptera, Membracidae) from the semi-arid region of northeastern Brazil. Rev. Bras. Entomol. 50(4): 473-474.

CREÃO-DUARTE, A.J., ANJOS, U.U. \& SANTOS, W.E. 2012. Diversidade de membracídeos (Hemiptera, Membracidae) e sobreposição de recursos tróficos em área do semi-árido. Iheringia Ser. Zool. 102(4): 355-467.

CREÃO-DUARTE, A.J., HERNÁNDEZ, M., ROTHÉA, R.R.A.D. \& SANTOS, W. 2016. Temporal variation of Membracidae (Hemiptera: Auchenorrhyncha) composition in areas of caatinga with different vegetation structures. Sociobiology. 63: 826-830.

CREÃO-DUARTE, A.J., ROTHÉA, R.R.A.D., LOURENÇO, A., CABRAL, V.A. \& EVANGELISTA O. 2017. Two remarkable new species of Notocera Amyot and Serville, 1843 (Hemiptera, Membracidae, Hypsoprorini) from the Brazilian Caatinga. Zootaxa. 4281(1): 77-89.

DEITZ, L.L. 1975. Classification of the higher categories of the New World treehoppers (Homoptera: Membracidae). North Carolina Agricultural Experiment Station, Technical Bulletin. 225:1-177.

DEL-CLARO, K. \& OLIVEIRA, P.S. 1999. Ant-Homoptera interactions in a neotropical savana: the honeydew-producing treehopper Guayaquila xiphias (Membracidae) and is associated ant fauna on Didymopanax vinosum (Araliaceae). Biotropica. 31:135-144.

DELABIE, J.H.C. 2001. Trophobiosis between Formicidae and Hemiptera (Sternorrhyncha and Auchenorrhyncha): an overview. Neotropical Entomology. 30: 501-516.

ERNESTO, M.V., LIBERAL, C.N., FERREIRA, A.F., ALVES, A.C.F., ZEPPELINI, D., MARTINS, C.F., PEREIRA-COLAVITE, A., CREÃODUARTE, A.J. \& VASCONCELLOS, A. 2018. Hexapod decomposers of Serra de Santa Catarina, Paraíba, Brazil: an area with high potential for conservation of Caatinga biodiversity. Biota Neotropica. 18(2): e20170410.

EVANGELISTA, O., SAKAKIBARA, A. \& TAKIYA, D.M. 2018. Membracidae in Catálogo Taxonômico da Fauna do Brasil. PNUD. Disponível em: $<\mathrm{http}: / /$ fauna.jbrj.gov.br/fauna/faunadobrasil/1304>. Acesso em: 01. Out. 2018.

FeitosA, A.F.M.A., WATABABE, T. \& MENEZES, M.A. DE. 2002. Unidades de Conservação no Semi-Árido Nordestino: O caso do Parque Ecológico Engenheiro Ávidos. Raízes. 21(1): 101-113.

FOGDEN, M.P.L. 1972. The seasonality and population dynamics of equatorial forest birds in Sarawak. Ibis. 114(3): 307-343.

FUNKHOUSER, W.D. 1951. Homoptera Family Membracidae. Genera Insectorum. 208:1-383.
FUNKHOUSER, W.D. 1927. General Catalogue of the Hemiptera. Fascicle I: Membracidae. Smith College Press. 581 pp.

GIULIETTI, A.M., BOCAGE NETA, A.L. DU, CASTRO, A.A.J.F., GAMARRA-ROJAS, C.F.L., SAMPAIO, E.V.S.B., VIRGÍNIO, J.F., QUEIROZ, L.P., FIGUEIREDO, M.A., RODAL, M.J.N., BARBOSA, M.R.V. \& HARLEY, R.M. 2003. Diagnóstico da vegetação nativa do bioma Caatinga. In Biodiversidade da Caatinga: áreas e ações prioritárias para a conservação (J.M.C. Silva, M. Tabarelli, M.T. Fonseca \& L.V. Lins orgs.). Ministério do Meio Ambiente, Brasília.

GUSMÃO, M.A.B. \& CREÃO-DUARTE, A.J. 2004. Diversidade e análise faunística de Sphingidae (Lepidoptera) em área de brejo e Caatinga no estado da Paraíba, Brasil. Revista Brasileira de Zoologia. 21(3):491-498.

HAVILAND, M.D. 1925. The Membracidae of Kartabo, Bartica District, British Guiana, with description of new species and bionomical notes. Zoologica. 6:229-290.

IANNUZZI, L., MAIA, A.C.D. \& VASCONCELOS, S.D. 2006. Ocorrência e sazonalidade de coleópteros buprestídeos em uma região de caatinga nordestina. Biociências. 14(2): 174-179.

JANZEN, D.H. \& SCHOENER, T.W. 1968. Differences in insect abundance and diversity between wetter and drier sites during a tropical dry season. Ecology. 49(1): 96-110.

KÖPPEN, W. 1948. Climatologia: con un estudio de los climas de la Tierra. Fondo de Cultura Economica, Ciudad de México.

LECCI, L.S., SIMÕES, T.V.D. \& CALOR, A.R. 2014. Plecoptera do Semiárido: conhecimento atual e desafios. In: Artrópodes do Semiárido. Biodiversidade e Conservação (F. Bravo \& A. Calor, eds.). Printmídia, Feira de Santana, p.91-98.

LIBERAL, C.N., FARIAS, A.M.I. DE, MEIADO, M.V., FILGUEIRAS, B.K.C. \& IANNUZZI, L. 2011. How habitat change and raisfall affect dung beetle diversity in Caatinga, a Brazilian semi-arid ecosystem. J. Insect. Sci. 11(114): 1-11

LOYE, J.E. 1987. Behavior of a Solitary Treehopper Microcentrus perditus (Membracidae: Homoptera). Journal of Kansas Entomological Society. 60(3):403-407.

LOPES, B.C. 1995. Treehoppers (Homoptera, Membracidae) in Southeastern Brazil: use of host plants. Revista Brasileira de Zoologia. 12:595-608.

MARIANO, R. \& COSTA, S.S. 2014. Ephemeroptera do Semiárido. In: Artrópodes do Semiárido. Biodiversidade e Conservação (F. Bravo \& A. Calor, eds.). Printmídia, Feira de Santana, p.69-81.

MCKAMEY, S.H. 1998. Taxonomic catalogue of the Membracoidea (exclusive of leafhoppers): second supplement to fascicle 1- Membracidae of the general catalogue of the Hemiptera. Memoirs of the American Entomological Institute. 60:1-377.

OLIVEROS, J.C. 2015. Venny. An interactive tool for comparing lists with Venn's diagrams. http://bioinfogp.cnb.csic.es/tools/venny/index.html (last access in $15 / \mathrm{mar} / 2018)$.

QUEIROZ, L.P., CARDOSO, D., FERNANDES, M.F. \& MORO, M.F. 2017. Diversity and Evolution of Flowering Plants of the Caatinga Domain. 2363 pp. In: Silva J.M.C., Leal I.R., Tabarelli M. (eds) Caatinga: The Largest Tropical Dry Forest Region in South America. Springer, Dordrech. 482 pp.

ROTHÉA, R.R.A. D. \& CREÃO-DUARTE, A.J. 2007. Duas novas espécies de Enchenopa Amyot \& Serville (Hemiptera, Membracidae) do semi-árido do Estado da Paraíba, Brasil. Rev. Bras. Entomol. 51(1): 35-37.

SILVA, J.M.C., BARBOSA, L.C.F., LEAL, I.R. \& TABARELLI, M. 2017. The Caatinga: Understanding the Challenges. 3-19. In: Silva J.M.C., Leal I.R., Tabarelli M. (eds) Caatinga: The Largest Tropical Dry Forest Region in South America. Springer, Dordrech. 482 pp.

TABARELLI, M., SILVA, J.M.C., SANTOS, A.M.M. \& VICENTE, A. 2000. Análise de representatividade das unidades de conservação de uso direto e indireto na Caatinga: análise preliminar. In: Silva, J.M.C. \& Tabarelli, M. (coord.) Workshop Avaliação e identificação de ações prioritárias para a conservação, utilização sustentável e repartição de benefícios da biodiversidade do bioma Caatinga. Petrolina, Pernambuco. www. biodiversitas.org.br./caatinga. 
VASCONCELLOS, A., ANDREAZZE, R., ALMEIDA. A.M., ARAUJO, H.F.P., OLIVEIRA, E.S. \& OLIVEIRA, U. 2010. Seasonality of insects in the semiarid Caatinga of northeastern Brazil. Rev. Bras. Entomol. 54 (3): 471-476.

VASCONCELLOS, A. \& MOURA, F.M.S. 2014. Térmitas de oito ecossistemas inseridos no Domínio do Semiárido Brasileiro. In Artrópodes do Semiárido. Biodiversidade e Conservação (F. Bravo \& A. Calor, eds.). Printmídia, Feira de Santana, p.99-109.

VELLOSO, A.L., SAMPAIO, E.V.S.B. \& PAREYN, F.G.C. 2002. Ecorregiões: Propostas Para O Bioma Caatinga. Associação Plantas Do Nordeste, Instituto De Conservação Ambiental The Nature Conservancy Do Brasil, Recife. 76p.

WALLACE, M. S. 2008. Occurrence of treehoppers (Hemiptera: Membracidae: Smiliinae) on oaks in Delaware Water Gap National Recreation Area, 20042006. Journal of Insect Science. 8:59.
WALTHER, B.A. \& MOORE, J. L. 2005. The concepts of bias, precision and accuracy, and their use in testing the performance of species richness estimators, with a literature review of estimator performance. Ecography. 28(6): 815-829.

WOLDA, H. 1978. Seasonal fluctuations in rainfall, food, and abundance of tropical insects. Journal Animal Ecology. 47:369-81.

WOOD, T.K. 1984. Life history patterns of tropical membracids (Homoptera: Membracidae). Sociobiology. 8:299-344.

WOOD, T.K. 1993. Diversity in the New World Membracidae. Annual Review of Entomology. 38:409-433.

ZANELLA, F.C.V. 2011. Evolução da biota da diagonal de formações abertas secas da América do Sul. 198-220 pp. In: CARVALHO, C.J.B. \& ALMEIDA, E.A.B. Biogeografia da América do Sul: Padrões e Processos. 306 pp.

Received: $19 / 06 / 2018$

Revised: 05/10/2018

Accepted: 14/01/2019

Published online: 11/02/2019 